Atıf için / For Citation: N. Sedefoğlu, H. Kavak, "Electrochemical and structural behavior of $\mathrm{Bi}$ doped $\mathrm{ZnO}$ materials obtained with solvothermal synthesis method", Süleyman Demirel Üniversitesi Fen Edebiyat Fakültesi Fen Dergisi, 16(1), 147-156, 2021.

\title{
Electrochemical and Structural Behavior of Bi Doped ZnO Materials Obtained with Solvothermal Synthesis Method
}

\author{
Nazmi SEDEFOĞLU ${ }^{* 1}$, Hamide KAVAK ${ }^{2}$ \\ ${ }^{1}$ Osmaniye Korkut Ata University, Arts and Science Faculty, Department of Physics, 80000, \\ Osmaniye, Turkey \\ ${ }^{2}$ Çukurova University, Arts and Science Faculty, Department of Physics, 01330, Adana, Turkey \\ *corresponding author e-mail: nazmisedefoglu@osmaniye.edu.tr
}

(Alınış / Received: 24.02.2021, Kabul / Accepted: 13.04.2021, Yayımlanma / Published: 27.05.2021)

\begin{abstract}
In this study, $\mathrm{Bi}$-doped $\mathrm{ZnO}$ and undoped $\mathrm{ZnO}$ nanomaterials have been synthesized by the solvothermal reaction method. The effect of $\mathrm{Bi}$ doping on the structural and electrochemical properties has been investigated by X-ray diffractions (XRD), X-ray photoelectron spectroscopy (XPS) and, scanning electron microscopy (SEM). As seen from Xray diffraction spectra performed on the bulk material, it has been clearly observed that both $\mathrm{Bi}$ doping changed the preferred orientation of the nanopowder as (101) and $\mathrm{Bi}^{+3}$ ions were expectedly entered the lattice. Furthermore, this result has been supported by photoelectron spectra. Scanning electron microscopy images have shown the shapes and distributions of nanostructures of the samples. As a result, it is thought that Bi doping is suitable for obtaining p-type conductivity in $\mathrm{ZnO}$ materials for the experimental processes we applied to samples in the study.
\end{abstract}

Key words: $\mathrm{ZnO}$ : Bi, Bi doping, Solvothermal synthesis

\section{Solvotermal Sentezleme Yöntemi ile Elde Edilen Bi Katkılı ZnO Malzemelerinin Elektrokimyasal ve Yapısal Davranışı}

Özet: $\mathrm{Bu}$ çalışmada, $\mathrm{Bi}$ katkılı $\mathrm{ZnO}$ ve katkısız $\mathrm{ZnO}$ nanomateryaller solvotermal reaksiyon yöntemi ile sentezlenmiştir. Bi katkısının yapısal ve elektrokimyasal özellikler üzerindeki etkisi X-ışını kırınımları (XRD), X-ışını fotoelektron spektroskopisi (XPS) ve taramalı elektron mikroskobu (SEM) ile araştırılmıştır. Katı malzeme üzerinde gerçekleştirilen X-ışını kırınım spektrumlarından görüldüğ̈ üzere, hem Bi katkılama nanotozun tercih edilen yöneliminin (101) olarak değiştirdiğini hem de $\mathrm{Bi}^{+3}$ iyonlarının beklenen şekilde kristal kafese girdiği açıkça gözlemlenmişdir. Ayrıca, bu sonuç fotoelektron spektrumları ile desteklenmiştir. Taramalı elektron mikroskobu görüntüleri, numunelerin nanoyapılarının şekillerini ve dağılımlarını göstermiştir. Sonuç olarak, çalışmada numunelere uyguladığımız deneysel işlemler için Bi katkılamanın $\mathrm{ZnO}$ malzemelerde $\mathrm{p}$ tipi iletkenliğin elde edilmesi bakımından uygun olduğu düşünülmektedir.

Anahtar kelimeler: $\mathrm{ZnO}: \mathrm{Bi}, \mathrm{Bi}$ katk1lama, Solvotermal sentezleme 


\section{Introduction}

$\mathrm{ZnO}$ is an important II-VI compound semiconductor with a wide direct bandgap, because of these properties it is considered a very important candidate for some application in optoelectronic devices like light-emitting diodes, laser diodes, flat panel, and photo-detectors [1-7]. It is important such application that to fabricate n-type and ptype stable $\mathrm{ZnO}$ however, intrinsic $\mathrm{ZnO}$ is n-type conductive due to native defect in the structure like oxygen vacancy, interstitial zinc, and hydrogen impurities [8]. To overcome the effect of the native defect on p-type conductivity, doping is the most convenient option. In recent years there are many groups works on p-type doping and many reports have been published on doping with group $\mathrm{V}$ element. Limpijumnong et al. [9] proposed $X_{Z n}-2 V_{Z n}$ acceptor model about the large-size-mismatched impurities in $\mathrm{ZnO}$. This mechanism stems from the low formation enthalpy of $\mathrm{X}_{\mathrm{Zn}}-2 \mathrm{~V}_{\mathrm{Zn}}$ complexes and $\mathrm{X}$ atoms occupy $\mathrm{Zn}$ antisite rather than $\mathrm{O}$ site.

In recent years, many experiments are conducted on group $\mathrm{V}$ element doping in $\mathrm{ZnO}$ like $\mathrm{N}$ [10, 11], P [12], As [13], and Sb [14] but there is very little paper are reported on bismuth doping in $\mathrm{ZnO}$. $\mathrm{Bi}_{\mathrm{Zn}}-2 \mathrm{~V}_{\mathrm{Zn}}$ mechanism is not deeply discussed and not enough evidence on the type of conductivity of $\mathrm{Bi}: \mathrm{ZnO}$. Moreover, their structural and electrochemical characteristics are not fully understood.

Hydrothermal synthesis refers to the use of water in the reaction as a solvent. solvothermal synthesis which typically uses other solvents including ethylene glycol, ethanol, acetone, and oleic acid is a broader terminology.

In this work, Bi-doped $\mathrm{ZnO}$ with solvothermal synthesis. There are many ways to produce that this nanostructure but solvothermal synthesis is mostly the preferred method because of its simplicity, the capability of large-scale production, and lowtemperature production [15-18]. And, doping mechanism of $\mathrm{Bi}$ into $\mathrm{ZnO}$ will be investigated by various methods. Moreover, in this work, samples are produced at 150 ${ }^{\circ} \mathrm{C}$ which is the optimum growth temperature for this synthesis.

\section{Material and Method}

Bismuth doped zinc oxide samples were prepared by the solvothermal solution synthesis method. All chemicals in the synthesis were analytic-grade reagents. In this experiment zinc nitrate hexahydrate $\mathrm{Zn}\left(\mathrm{NO}_{3}\right)_{2} \cdot 6 \mathrm{H}_{2} \mathrm{O}$ was used as a starting material. DI (distilled) water and acetone were used as a solvent. Hexamethylenetetramine $\left(\mathrm{C}_{6} \mathrm{H}_{12} \mathrm{~N}_{4}\right)$ and bismuth chloride $\left(\mathrm{BiCl}_{3}\right)$ were used as stabilizers and dopant sources respectively. The concentration which is $\mathrm{Bi}^{+3}$ molar percentage in the solution was changed from 0 to 10 at $\%$ in the solution. The mixture was magnetically stirred for $1 \mathrm{~h}$ to get a homogeneous solution. Then the solution was put into the Teflon liners, and heated to $150{ }^{\circ} \mathrm{C}$ for $24 \mathrm{~h}$, and cooled down to room temperature $0.1^{\circ} \mathrm{C} / \mathrm{min}$. 


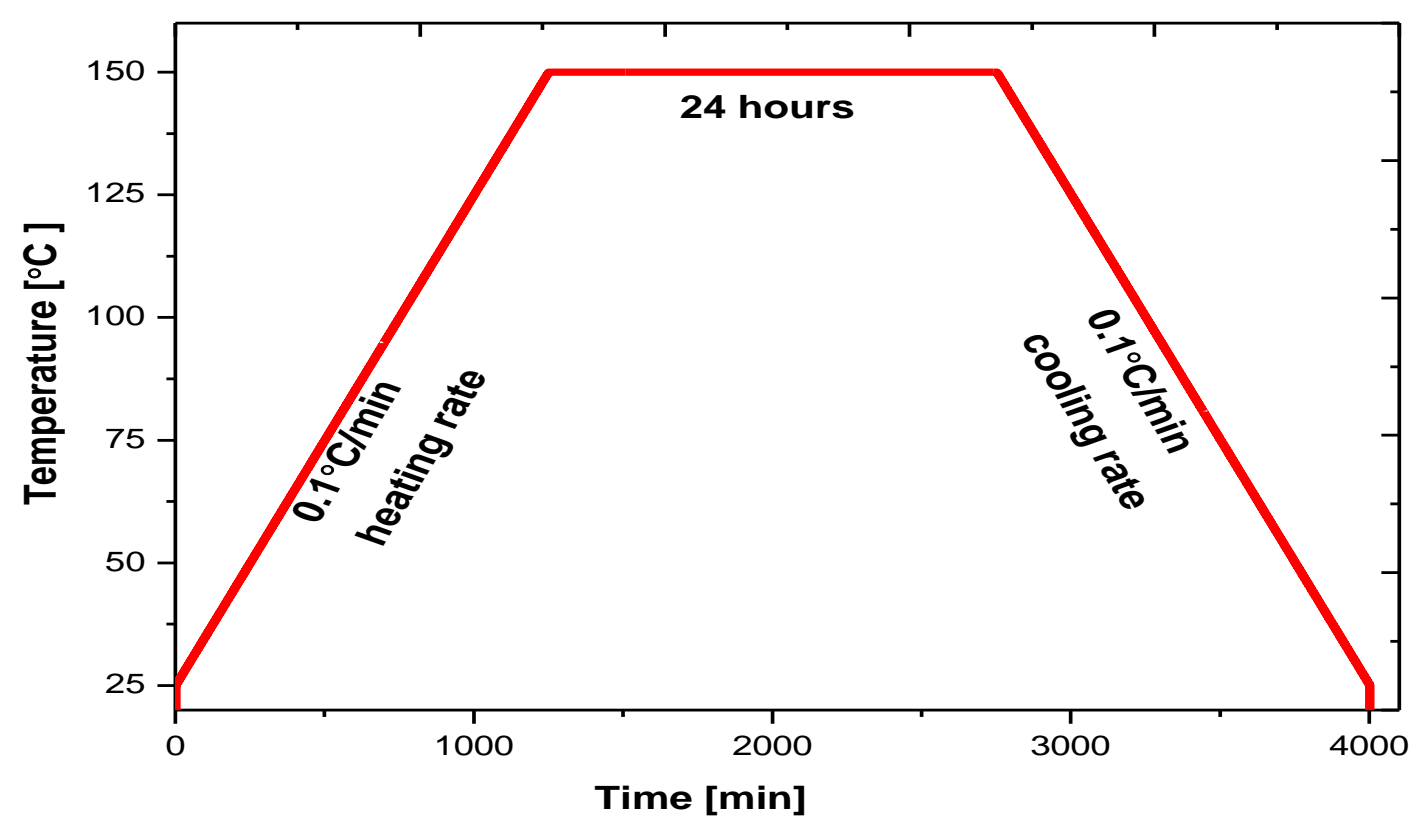

Figure 1. Synthesis graph for reactions time $(\mathrm{min})$ vs temperature $\left({ }^{\circ} \mathrm{C}\right)$

The residual solution was filtered and rinsed with DI water and dried at $90{ }^{\circ} \mathrm{C}$ in the air for an hour, after then dried powder calcinated at $800^{\circ} \mathrm{C}$ for $12 \mathrm{~h}$ as shown in Figure 1 schematically. X-ray powder diffraction analysis of Bi-doped $\mathrm{ZnO}$ was performed at room temperature in the angular range of $2 \theta=20^{\circ}-70^{\circ}$ with a scan step width of $0.02^{\circ}$ and a fixed counting time of 1 s/step using an automated Rigaku Ultima IV X-ray diffractometer equipped with $\mathrm{Cu} \mathrm{K} \alpha$ radiation of wavelength $\lambda=1.5418 \AA$. Crystallite sizes are calculated with Scherrer's method using the (101) orientation of ZnO. X-ray photoelectron spectroscopy was used to analyze the compositional properties of the sample with Thermo Scientific ESCALAB 250Xi. Pass energy and step within XPS measurements are $50 \mathrm{eV}$ and $0.1 \mathrm{eV}$ respectively. SEM image has been taken from Hitachi SU8030.

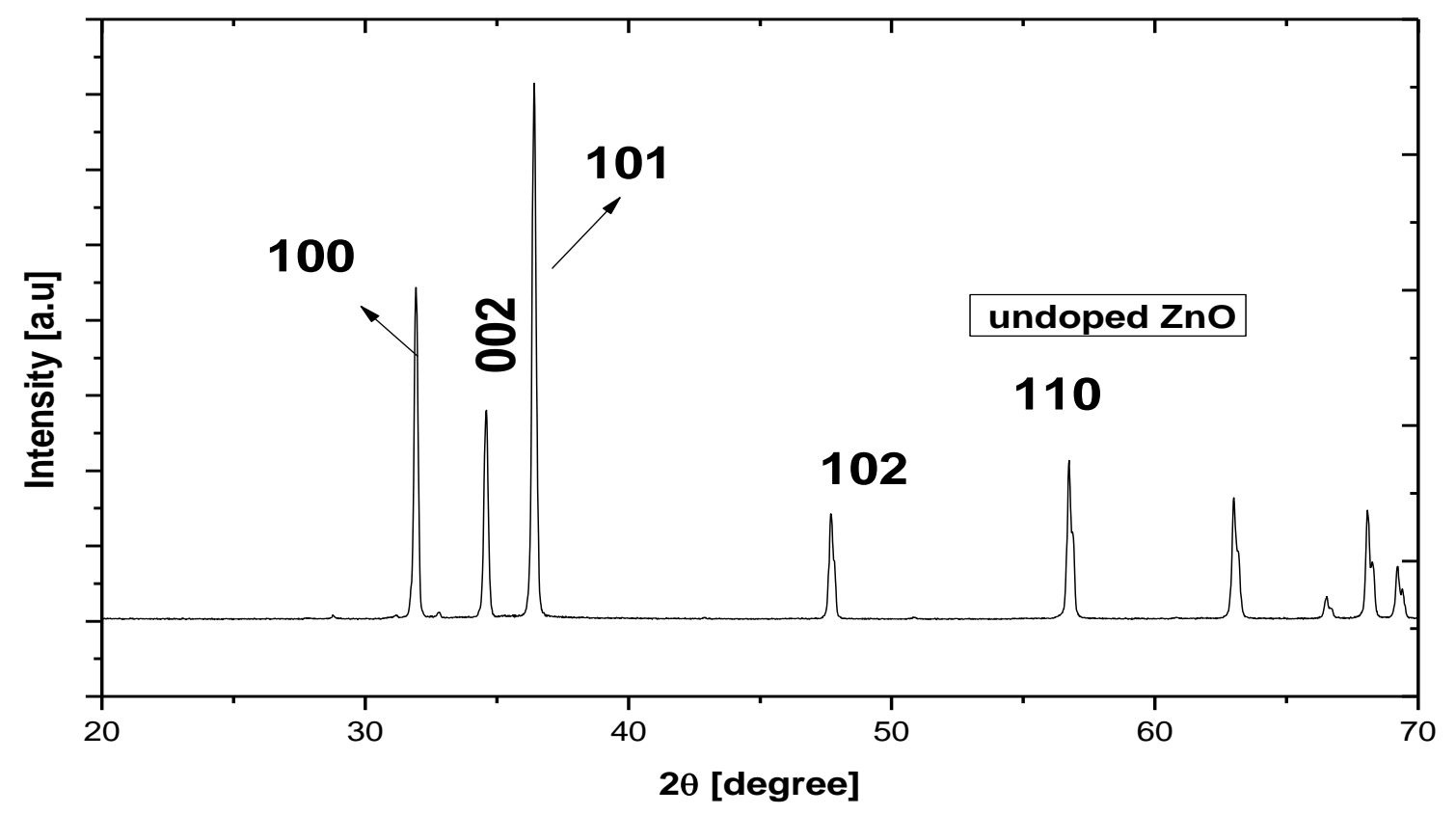

Figure 2. X-ray diffraction pattern of undoped $\mathrm{ZnO}$ sample 


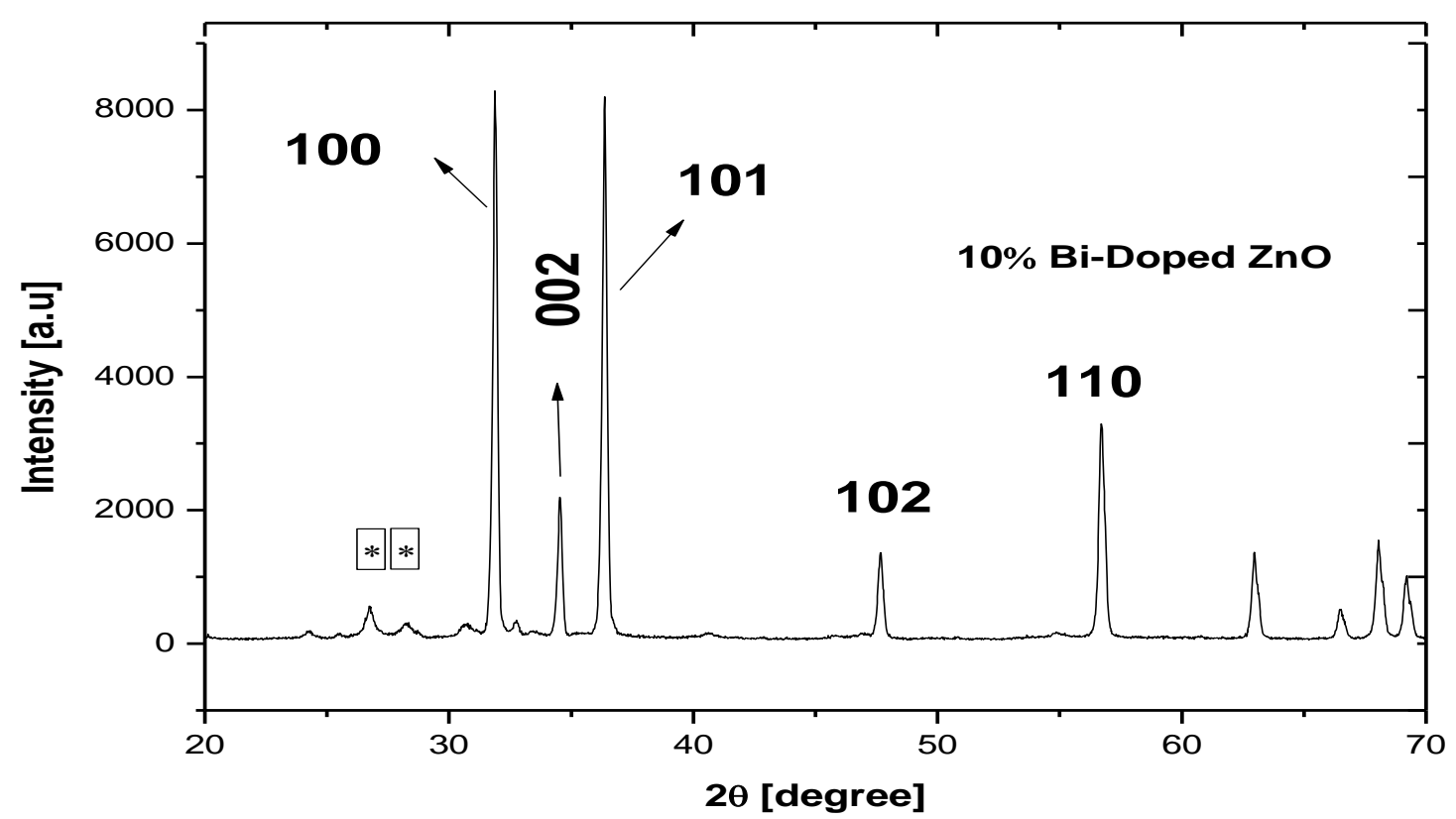

Figure 3. X-ray diffraction pattern of $10 \% \mathrm{Bi}$-doped $\mathrm{ZnO}$ sample * shows secondary phases

\section{Result and Discussion}

XRD patterns of the undoped and Bi-doped samples are shown in Figures 2-5. Figure 2 shows the undoped XRD pattern of $\mathrm{ZnO}$ which crystallized in hexagonal wurtzite structure in mixed-orientation and all diffraction peaks can be indexed as standard wurtzite $\mathrm{ZnO}$ [19]. Undoped, $1 \%$ and 3\% Bi-doped $\mathrm{ZnO}$ samples show only standard wurtzite $\mathrm{ZnO}$ peaks, there is not any secondary diffraction peak however $5 \%$ and $10 \%$ Bi-doped $\mathrm{ZnO}$ shows some secondary peaks as in Figure 5 and Figure 3. Moreover, Figure 5 shows that increasing the doping concentration causes a slight decrease in the (002) diffraction peak as reported by Kumar et al. [20] and increased the (101) differaction peaks. This increment on (101) shows that increasing the doping concentration changes the preferred orientation of $\mathrm{ZnO}$ [21]. The shift is shown in Figure 4 also indicates that $\mathrm{Bi}^{+3}$ ions are substituted into the $\mathrm{Zn}^{+2}$ ions site and [22]. Additionally, doping the materials with a bigger ionic radius causes a shift to higher angles in XRD diffraction peaks. This estimation is also supported by a previous study that mentions the huge differences between the atomic radius of $\mathrm{Bi}^{+3}(1.20 \AA)$ and $\mathrm{Zn}^{+2}$ $(0.74 \AA)[23]$. 


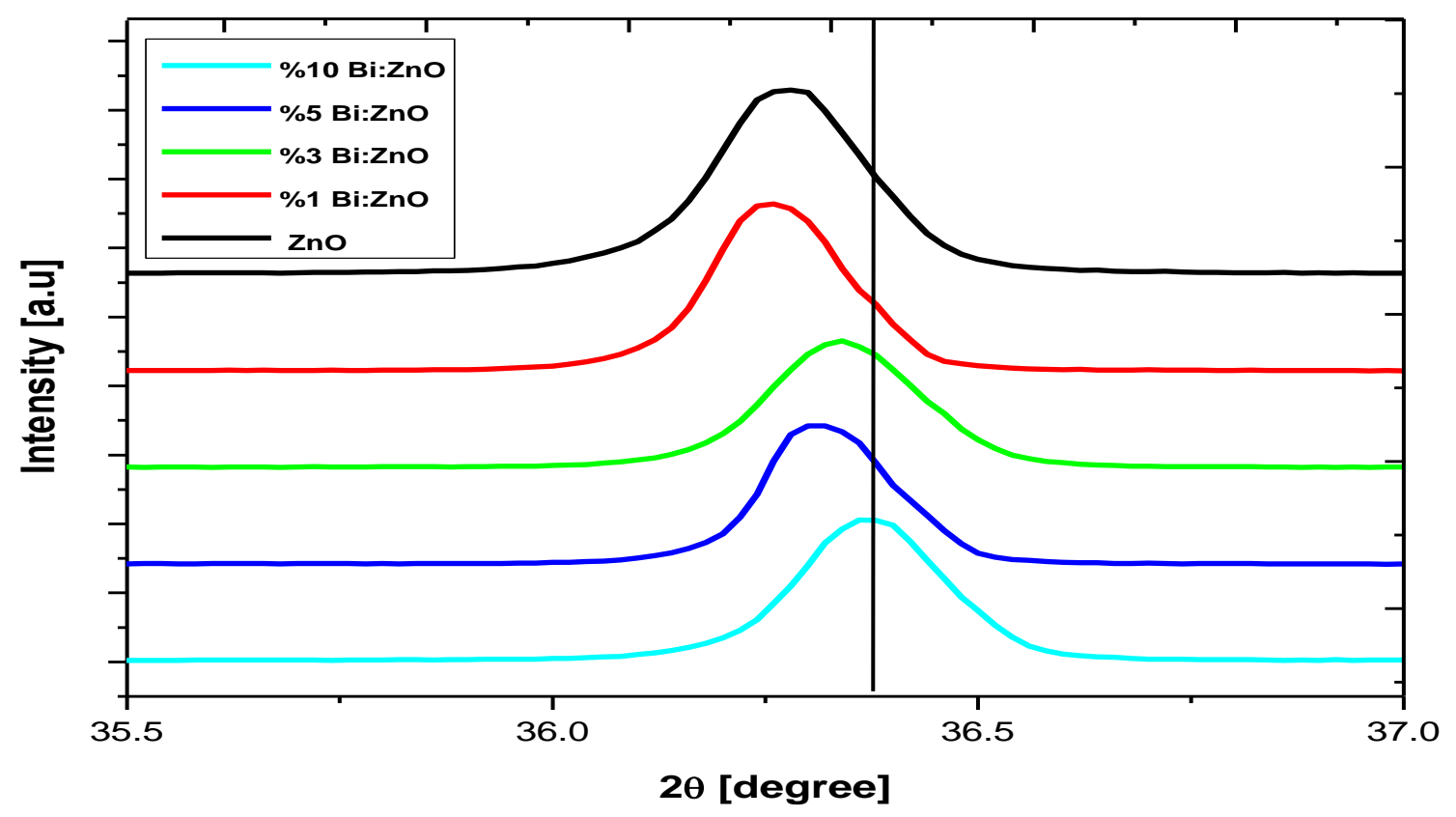

Figure 4. XRD diffraction pattern of (101) diffraction peaks of undoped and Bi-doped $\mathrm{ZnO}$ sample

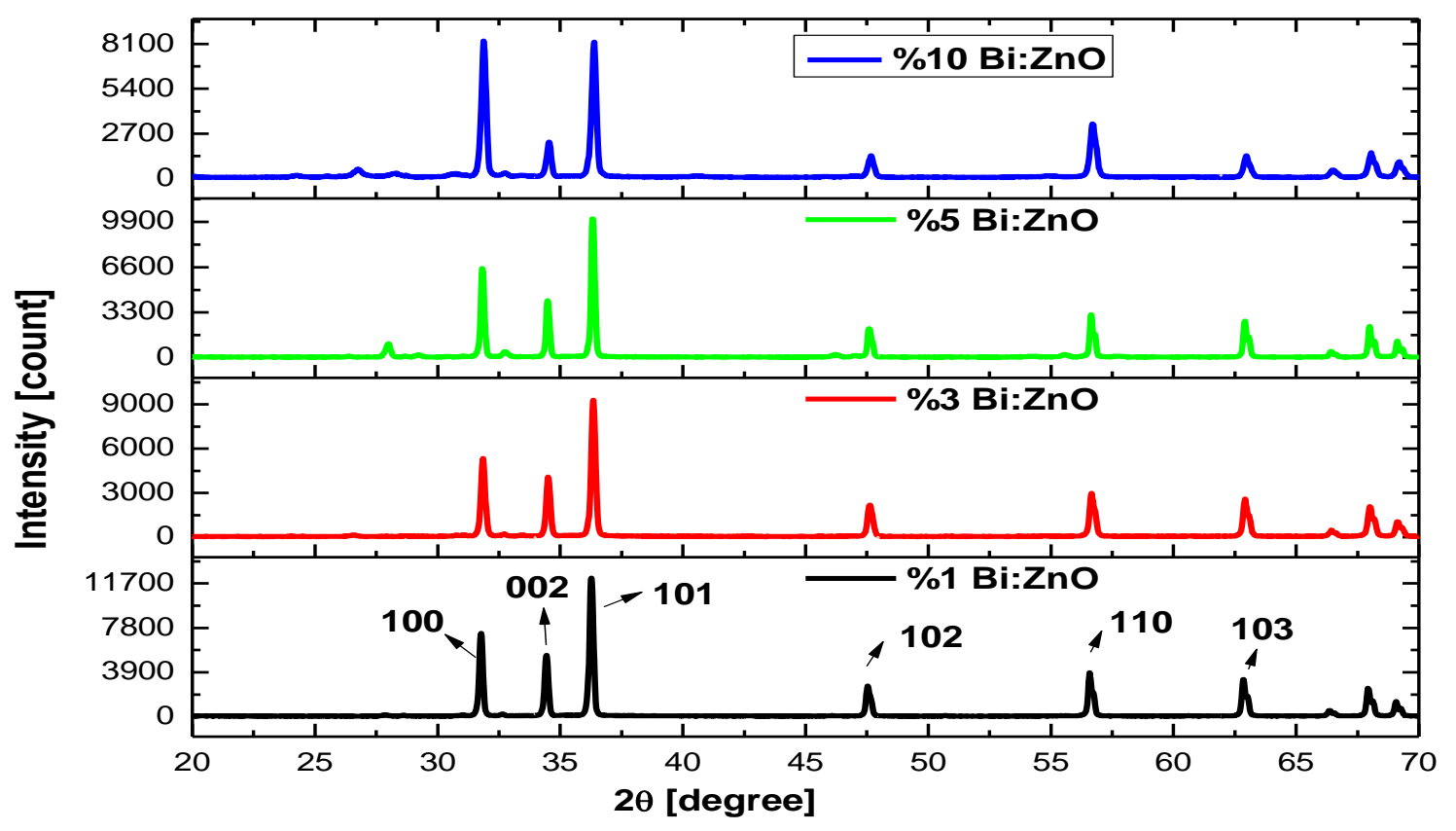

Figure 5. XRD diffraction pattern of Bi-doped $\mathrm{ZnO}$ samples

FWHM of the samples given in Figure 6, shifts to the higher angles with an increment of Bi doping. The measured FWHM value for (101) diffraction peaks was measured as 0.140 for pure $\mathrm{ZnO}$ and 0.182 for the $\% 10 \mathrm{Bi}$-doped $\mathrm{ZnO}$. Similarly, it was observed that the FWHM values of the (100) and (002) diffraction peaks increased with the increase in the doping ratio. These results also verify that $\mathrm{Bi}$ atoms are successfully doped into the $\mathrm{ZnO}$ lattice and cause lattice expansions in the $\mathrm{ZnO}$ crystals $[19,24]$. The crystallite size of the samples was determined by the Debye-Scherer formula given in Eq. 1 [25]: 


$$
d=\frac{K \cdot \lambda}{\beta \cos \theta_{h k l}}
$$

where $\lambda$ is the wavelength of XRD, $\beta$ is the FWHM of the selected peak $\mathrm{K}$ is a constant which is taken as 0.9 and $\theta$ is the Bragg angle of a selected peak. For (101), the crystallite size of $\mathrm{ZnO}$ samples slightly alters from $7.84 \mathrm{~nm}$ for $\% 10 \mathrm{Bi}: \mathrm{ZnO}$ to $9.95 \mathrm{~nm}$ for pure $\mathrm{ZnO}$.

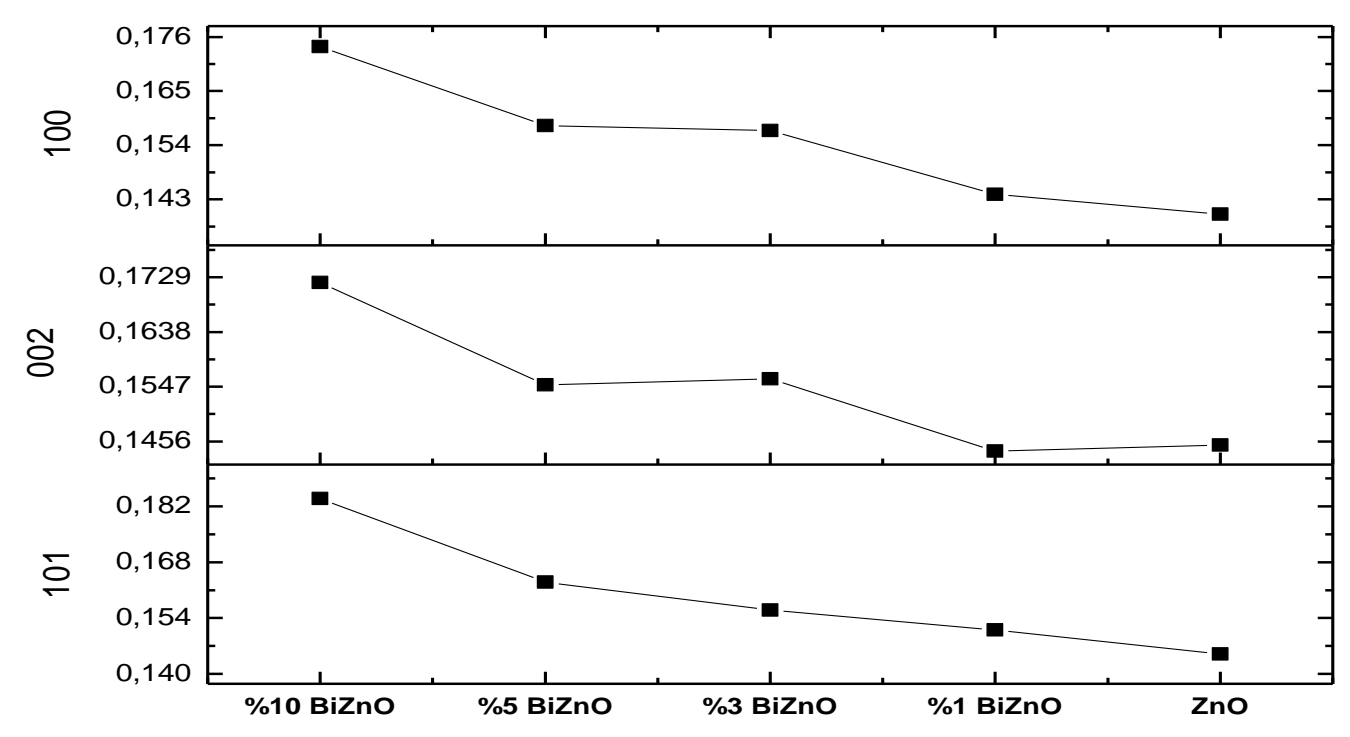

Figure 6. FWHM values of $\mathrm{Bi}^{+3}$ doped and undoped $\mathrm{ZnO}$ samples for $[101,002,100]$ orientation

XPS was used to characterize the electrochemical composition of the $\mathrm{ZnO}$ : Bi samples. XPS spectra of Bi-doped ZnO are placed in Figure 7. In Figures 7 a, b, c, and d, it can be seen that $4 \mathrm{f}$ core-level spectra of 1,3,5, and 10\% doped $\mathrm{ZnO}$ respectively. And Figure $7 \mathrm{e}$ and $\mathrm{f}$ show us Carbon $1 \mathrm{~s}$ core-level spectra and survey compositional analysis of $10 \%$ doped $\mathrm{ZnO}$ respectively. $\mathrm{C}$ 1s peaks are used to calibrate the spectra. $\mathrm{C}$ 1s peaks are settled to $284.6 \mathrm{eV}$ for each sample [26]. According to Figure 7, there is an inversely proportional ratio between the doping concentration and $\mathrm{Bi} 4 \mathrm{f}$ core-level spectra peaks. As can be seen, while doping concentration increased, the location of $\mathrm{Bi}$ $4 \mathrm{f}_{5 / 2}$ decreased from 159.4 to 158.4 . Also, $\mathrm{Bi} 4 \mathrm{f}_{7 / 2}$ peaks locations in the spectra are decreased. There are no Bi $4 \mathrm{f}_{72}$ peaks on the XPS spectra located below the $157 \mathrm{eV}$. This shows us Bi-O bonding was established rather than $\mathrm{Zn}-\mathrm{Bi}$ bonding in the lattice accordingly $\mathrm{Xu}$ et al. [27]. $\mathrm{Bi} 4 \mathrm{f}_{7 / 2}$ peaks located about $163.7 \mathrm{eV}$ showed that $\mathrm{Bi}^{+3}$ is the major charge state and $\mathrm{BiO}$ is produced in the $\mathrm{Bi}$-doped $\mathrm{ZnO}$ by substituting for $\mathrm{Zn}$ as $\mathrm{Bi}_{Z n}[27,28]$. The shift of the peaks may be caused by changing electromagnetic field inside the sample [29]. XPS and XRD measurements are in compliance with each other. 
a

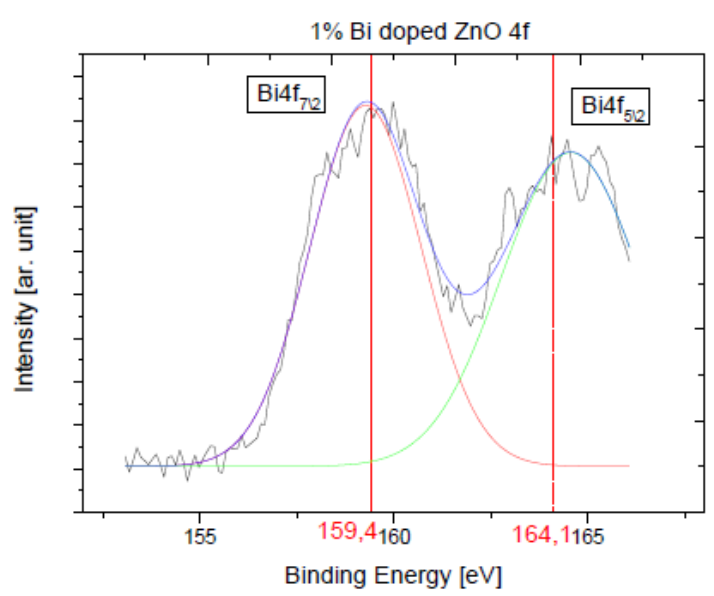

C

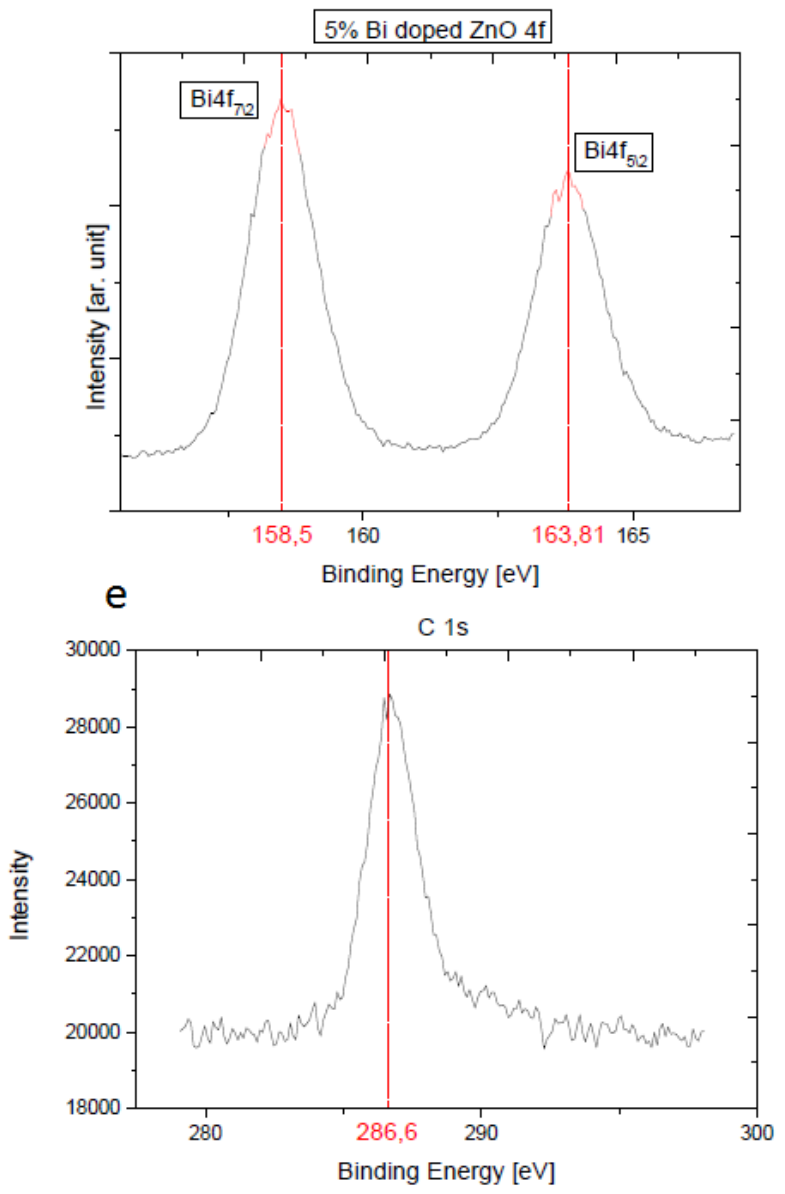

b

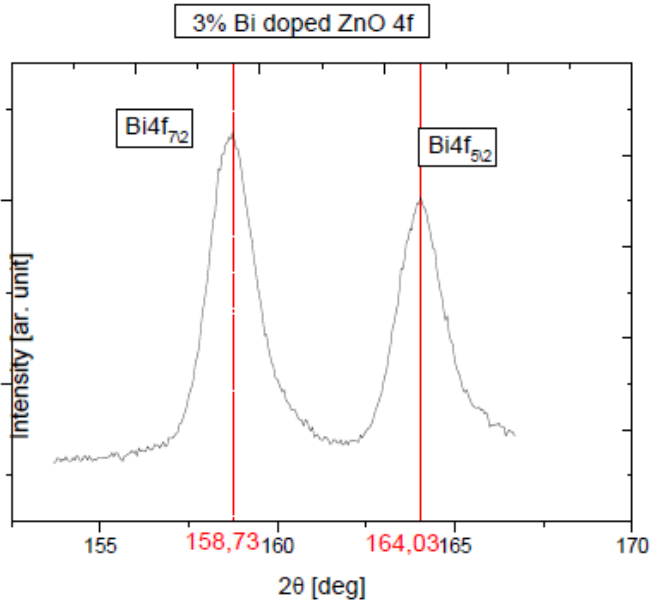

d
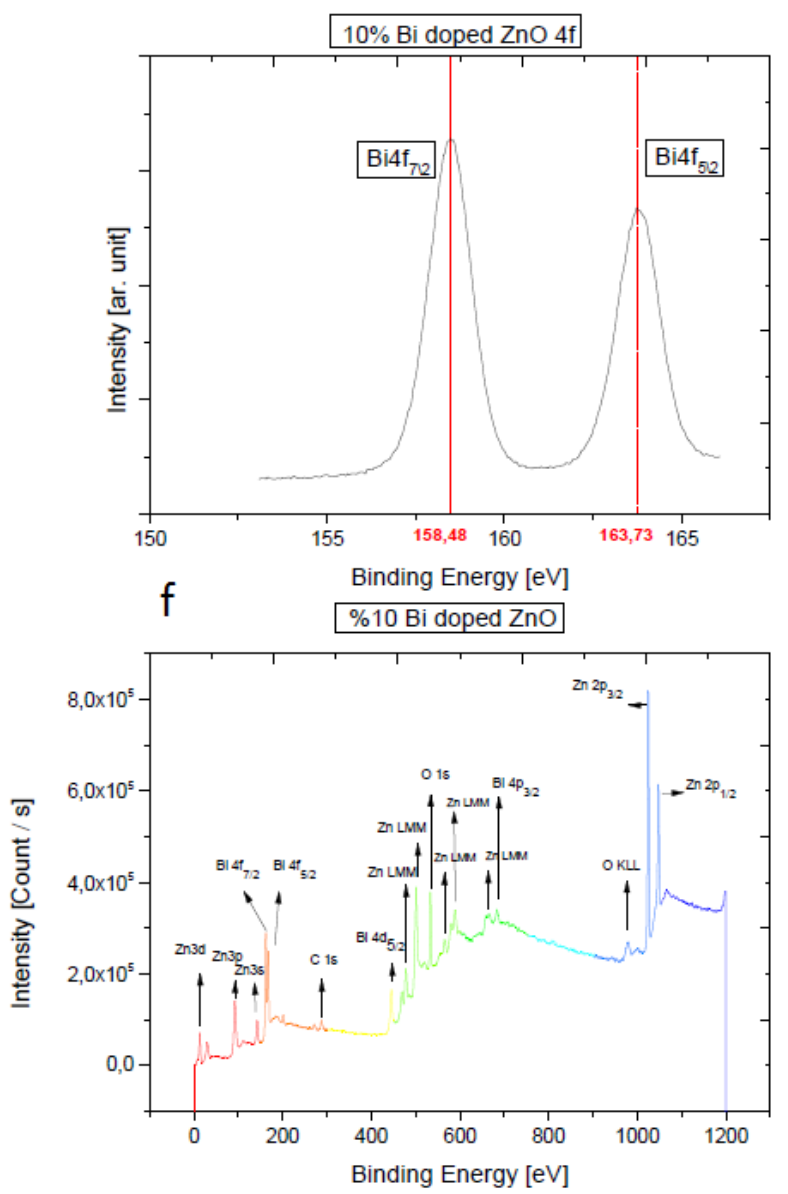

Figure 7. XPS core-level spectra of $\mathrm{Bi}$-doped $\mathrm{ZnO}$ a) b) c) d) is the $4 \mathrm{f}$ core-level spectra of $\mathrm{Bi}$ for $1,3,5$, and $10 \%$ doped $\mathrm{ZnO}$ respectively e) f) is the $\mathrm{C} 1 \mathrm{~s}$ core-level spectra and survey spectra of $10 \%$ doped $\mathrm{ZnO}$

As seen in the SEM images (Figures 8,9), particles with a size of 1-2 $\mu \mathrm{m}$ and less than $1 \mu \mathrm{m}$ appear to have formed nonhomogeneous. The planes on the surfaces of the particles are noticed and it can be said that they have a hexagonal structure. It is seen that the particles have different orientations, angle differences, and large thick bars on their surfaces. When examined in Figure. 8, it is thought that small particles come together to form these large heaps. 

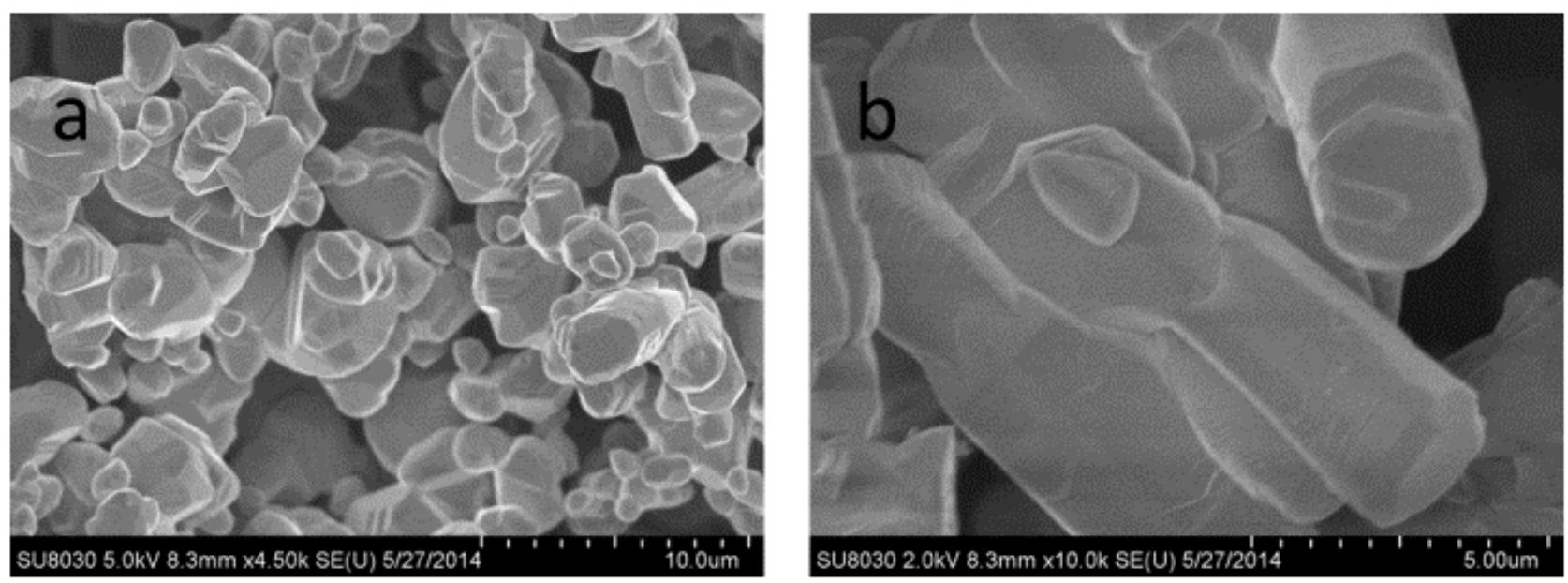

Figure 8. SEM image of $3 \% \mathrm{Bi}: \mathrm{ZnO}$ sample a) with $4500 \mathrm{X} \mathrm{b)} 10000 \mathrm{X}$ magnification

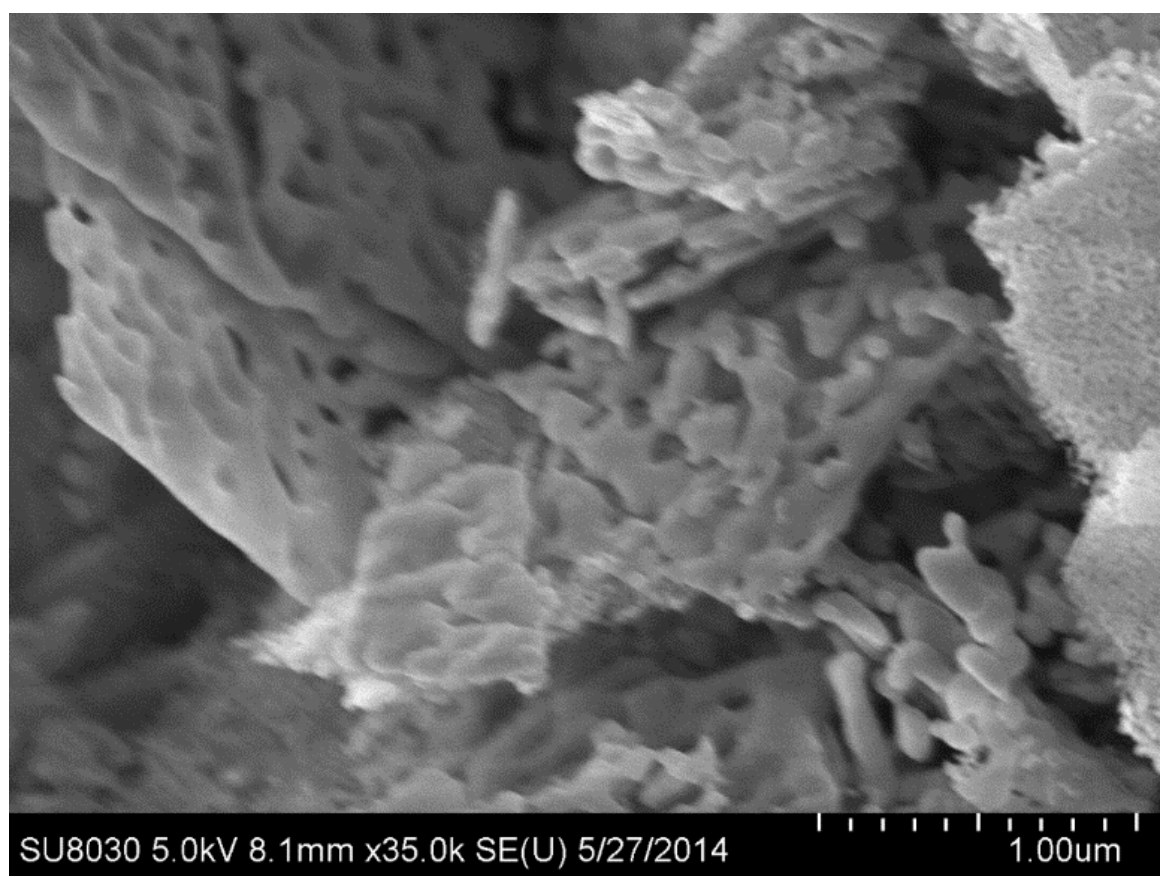

Figure 9. SEM image of pure $\mathrm{ZnO}$ sample with $35000 \mathrm{X}$ magnification

\section{Conclusion and Comment}

The $\mathrm{ZnO}$ : $\mathrm{Bi}$ samples were synthesized by the solvothermal synthesis method and calcinated $800{ }^{\circ} \mathrm{C}$ for 12 hours in the air atmosphere. The XRD patterns showed that Bi doping was successful and the change in doping concentration has improved the crystal quality up to $5 \%$. After this doping concentration was exceeded, secondary phases were observed. Further, XRD peaks of (101) oriantation shifted to higher angles with increasing doping concentration. Additionally, while the concentration of Bi doping in the samples was increased, (101) diffraction peaks intensity was increased but the intensity of (002) peaks was decreased which are interpreted as doping were achieved. The XPS results showed that the dopant atoms replaced the $\mathrm{Zn}$ atoms in the lattice, producing the $\mathrm{Bi}_{\mathrm{Zn}}$ defect. In XPS measurement, there was not any $\mathrm{Bi} 4 \mathrm{f}_{7 / 2}$ peaks lower than $157 \mathrm{eV}$ which means $\mathrm{Bi}^{+3}$ is the preferred oxidation state. Lastly, from these given 
XPS results, it is concluded that the $\mathrm{Bi}^{+3}$ ion is a suitable candidate to form the $\mathrm{X}_{\mathrm{Zn}}{ }^{-}$ $2 \mathrm{~V}_{\mathrm{Zn}}$ complex and successfully produced in this study.

\section{Author Statement}

Nazmi SEDEFOGLU: Methodology, Investigation, Review and Editing, Conceptualization, Investigation, Original Draft Writing

Hamide KAVAK: Methodology, Supervision, Observation, Advice

\section{Acknowledgment}

This study has been financially supported by the Department of Scientific Research Project (BAP) of Çukurova University as project number FEF2013D30.

\section{Conflict of Interest}

As the authors of this study, we declare that I do not have any conflict of interest statement.

\section{Ethics Committee Approval and Informed Consent}

As the authors of this study, we declare that I do not have any ethics committee approval and/or informed consent statement.

\section{References}

[1] D. C. Look, "Recent advances in $\mathrm{ZnO}$ materials and devices," Mater. Sci. Eng., B, 80, 383-387, 2001.

[2] H. Kim, J. S. Horwitz, W. H. Kim, A. J. Makinen, Z. H. Kafafi, and D. B. Chrisey, "Doped ZnO thin films as anode materials for organic light-emitting diodes," Thin Solid Films, 420, 539-543, 2002.

[3] C. Yuen, S. F. Yu, S. P. Lau, and G. C. K. Chen, "Design and fabrication of ZnO light-emitting devices using filtered cathodic vacuum arc technique," J. Cryst.Growth, 287, 204-212, 2006.

[4] F. C. M. Vandepol, "Thin Film ZnO - properties and applications," Am. Ceram. Soc. Bull, 69, 19591965, 1990.

[5] R.-Y. Yang, M.-H. Weng, C.-T. Pan, C.-M. Hsiung, and C.-C. Huang, "Low-temperature deposited $\mathrm{ZnO}$ thin films on the flexible substrate by cathodic vacuum arc technology," Appl. Surf. Sci., 257, 7119-7122, 2011.

[6] K. Chung, C.-H. Lee, and G.-C. Yi, "Transferable GaN layers grown on ZnO-coated graphene layers for optoelectronic devices," Sci., 330, 655-657, 2010.

[7] M. H. Huang, S. Mao, H. Feick, H. Q. Yan, Y. Y. Wu, H. Kind, et al., "Room-temperature ultraviolet nanowire nanolasers," Sci., 292, 1897-1899, 2001.

[8] S. B. Zhang, S. H. Wei, and A. Zunger, "Intrinsic n-type versus p-type doping asymmetry and the defect physics of ZnO," Phys. Rev. B, 63 (7), 075205, 2001.

[9] S. Limpijumnong, S. B. Zhang, S. H. Wei, and C. H. Park, "Doping by large-size-mismatched impurities: The microscopic origin of arsenic- or antimony-doped p-type zinc oxide," Phys. Rev. Lett., 92 (15), 155504, 2004.

[10]P. Sikam, C. Sararat, P. Moontragoon, T. Kaewmaraya, and S. Maensiri, "Enhanced thermoelectric properties of N-doped ZnO and SrTiO3: A first-principles study," Appl. Surf. Sci., 446, 47-58, 2018.

[11] M. Moalem-Banhangi, N. Ghaeni, and S. Ghasemi, "Saffron derived carbon quantum dot/N-doped $\mathrm{ZnO}$ /fulvic acid nanocomposite for sonocatalytic degradation of methylene blue," Synth. Met., 271, 116626, 2021.

[12]S. Swathi, R. Yuvakkumar, G. Ravi, E. S. Babu, D. Velauthapillai, and S. A. Alharbi, "Morphological exploration of chemical vapor-deposited P-doped $\mathrm{ZnO}$ nanorods for efficient photoelectrochemical water splitting," Ceram. Int., 47 (5), 6521-6527, 2021.

[13]S. Y. Wakhare and M. D. Deshpande, "Structural, electronic and optical properties of metalloid element (B, Si, Ge, As, Sb, and Te) doped g-ZnO monolayer: A DFT study," J. Mol. Graph. Model., 101, 107753, 2020.

[14]C.-Q. Luo, S.-C. Zhu, C. Xu, S. Zhou, C.-H. Lam, and F. C.-C. Ling, "Room temperature ferromagnetism in Sb doped ZnO," J. Magn. Magn. Mater., 529, 167908, 2021.

[15]H. Zhang, X. Y. Ma, Y. J. Ji, J. Xu, and D. R. Yang, "Single crystalline US nanorods fabricated by a novel hydrothermal method," Chem. Phys. Lett., 377, 654-657, 2003.

[16]H. Zhang, Y. J. Ji, X. Y. Ma, J. Xu, and D. R. Yang, "Long Bi2S3 nanowires prepared by a simple hydrothermal method," Nanotechnology, 14, 974-977, 2003. 
[17] Y. Jiang, Y. Wu, S. Y. Zhang, C. Y. Xu, W. C. Yu, Y. Xie, et al., "A catalytic-assembly solvothermal route to multiwall carbon nanotubes at a moderate temperature," J. Am. Chem., 122, 12383-12384, 2000 .

[18] J. H. Zhan, X. G. Yang, D. W. Wang, S. D. Li, Y. Xie, Y. N. Xia, et al., "Polymer-controlled growth of CdS nanowires," Adv. Mater., 12 (8), 1348-1351, 2000.

[19]F. Chouikh, Y. Beggah, and M. S. Aida, "Optical and electrical properties of Bi doped ZnO thin films deposited by ultrasonic spray pyrolysis," J. Mater. Sci.: Mater. Electron, 22, 499-505, 2011.

[20]N. S. Kumar, K. V. Bangera, C. Anandan, and G. K. Shivakumar, "Properties of ZnO:Bi thin films prepared by spray pyrolysis technique," J. Alloy. Compd., 578, 613-619, 2013.

[21]C. H. Lee, K. S. Lim, and J. S. Song, "Highly textured ZnO thin films doped with indium prepared by the pyrosol method," Sol. Energy Mater. Sol. Cells, 43, 37-45, 1996.

[22] M. Jiang, X. Liu, and H. Wang, "Conductive and transparent Bi-doped ZnO thin films prepared by rf magnetron sputtering," Surf. Coat. Technol., 203, 3750-3753, 2009.

[23]T. Ait Ahcene, C. Monty, J. Kouam, A. Thorel, G. Petot-Ervas, and A. Djemel, "Preparation by solar physical vapor deposition (SPVD) and nanostructural study of pure and $\mathrm{Bi}$ doped $\mathrm{ZnO}$ nanopowders," J. Eur. Ceram. Soc., 27, 3413-3424, 2007.

[24]E. F. Keskenler, S. Aydin, G. Turgut, and S. Dogan, "Optical and structural properties of bismuth doped $\mathrm{ZnO}$ thin films by sol-gel method: Urbach rule as a function of crystal defects," Acta Phys. Polon. A, 126, 782-786, 2014.

[25] A. L. Patterson, "The Scherrer Formula for X-Ray Particle Size Determination," Phys Rev., 56, 978982, 1939.

[26] K. Wu, Z. Jia, L. Zhou, S. Yuan, and J. Cui, "Study on the effect of methanol on the morphology and optical properties of ZnO," Optik, 205, 164250, 2020.

[27]X. Xu, Y. Shen, N. Xu, W. Hu, J. Lai, Z. Ying, et al., "Large-sized-mismatched group-V element doped $\mathrm{ZnO}$ films fabricated on silicon substrates by pulsed laser deposition," Vacuum, 84, 1306$1309,2010$.

[28] V. S. Dharmadhikari, S. R. Sainkar, S. Badrinarayan, and A. Goswami, "Characterisation of thin films of bismuth oxide by X-ray photoelectron spectroscopy," J. Electron. Spectrosc., 25, 181-189, 1982.

[29] J. B. Zhong, J. Z. Li, Y. Lu, X. Y. He, J. Zeng, W. Hu, et al., "Fabrication of Bi 3+-doped ZnO with enhanced photocatalytic performance," Appl. Surf. Sci., 258, 4929-4933, 2012. 